\title{
Haunting Poe's Maze: \\ Investigative Obsessions in the Weird Fictions of Stefan Grabiński and H. P. Lovecraft
}

\author{
Pawel Pyrka \\ SWPS University of Social Sciences and Humanities in Warsaw \\ ppyrka@swps.edu.pl
}

Received 16 August 2017; accepted 30 October 2017.

\begin{abstract}
The article is a comparative reading and analysis of selected works by two eminent authors of weird fiction, Stefan Grabiński and Howard Phillips Lovecraft, the goal of which is to trace two (independent) trajectories of development of ideas concerning "weird" story writing, as established, in pre-modern context, by Edgar Allan Poe. The two authors appear to suffer from a combination of tragically inherent inability to write "like" Poe, with a haunting desire to do so. Exhibiting understanding of the Poesque discourse, they are driven to invent strategies to cope with the resulting textual neuroses - a way out of the discursive "maze" of Poe's craft, a way that is always already shut.

Where Lovecraft's “mechanistic materialism" finds its expression in an indifferent cosmos, populated by alien beings, whose influence seems to be inscribed in the fabric of his textual realities, Grabiński's sense of "amazement" is deployed internally, with psychological constructs overshadowing the "objective" reality. Both discourses, however, spring from one tradition of horror, and from the unexorcised trace of Poe's spectre. The two authors' ambivalent relation with modern sensibilities results in a series of obsessive investigations into the ideological underpinnings of art, philosophy and science.
\end{abstract}

Keywords: weird fiction; Poe; Lovecraft; Grabiński; haunting; obsession. 


\section{Tracing the Labyrinth}

Edgar Allan Poe's 1843 story “The Tell-Tale Heart” opens with the following confession:

It is impossible to say how first the idea entered my brain; but, once conceived, it haunted me day and night. Object there was none. Passion there was none. I loved the old man. He had never wronged me. He had never given me insult. For his gold I had no desire. I think it was his eye! (Poe, 2011, p. 284)

The passage gives voice to the murderer's own admission and definition of his obsession and its pattern of development into murderous compulsion. And yet inevitably, the narrator's words explain very little to the readers, instead planting in their minds that very same species of an idea, one supposed to haunt them day and night, with no apparent goal, no identifiable emotion, and, as it turns out, no intellectual satisfaction to be had in the end. The narrative voice thus becomes that of a siren, luring readers into the labyrinth of lies, initiating a play of uncertainties, constructed and enacted with the neatness available only to obsessive-compulsive minds and texts.

Poe's preoccupation with, and emphasis on, structural unity, expressed in "The Philosophy of Composition" (Poe, 1984, p. 13), allow precisely for such a mode of entrapment. Envisioning a text as a carefully designed undertaking, a structured experience, directing the mind of the reader through a series of narrative encounters leading to a very specific place, enhances the sense of highly organized mental space in which Poe's characters exist. The maze-like structures emerge from the texts in the form of a dilapidated family estate (accompanied by family relations of disconcerting complexity), twisting and turning underground passages and vaults beneath a palazzo, labyrinthine streets of a crowded metropolis, or, strikingly, intricacies of irrational thought produced by the texts' narrators.

Immersed in the text and "a-mazed" by its confines, the reader intuitively seeks a way out, frequently intoxicated by the strangeness of the circumstances and enamoured with the idea of the final revelation - one capable of offering peace to the obsessing mind. And yet, more often than not, they are thrown back to the beginning, the state of confusion, without any real progress, absent answers and understanding, walled in like the unfortunate Fortunato, punished for some imagined slight (Poe, 2011, p. 214). And so the journey through the maze becomes in a sense the sum total of the experience: as the house of Usher falls (Poe, 2011, p. 195), as Ligeia reinserts herself into the narrator's life (2011, p. 410), as the tell-tale heart beats towards the frantic confession, the text closes, the narrative voice loses its power to describe, the seeking mind of the reader hits the wall of the labyrinth.

Poe's maze, envisioned as a "dream within a dream," and constructed to be "seen" and to "seem" (Poe, 2011, p. 675), on the crossroads of reality and fiction is in effect already an apparition, a half-being. A set of textual restrictions in the form of silences, understatements and displays of circular narrative logic, the labyrinth emerges as at once a metaphor of psychological entrapment and an epistemological quest for answers. It is a structure which must always be explored, a veil to be pierced, a cypher to be decrypted, revealed 
and unearthed. The labyrinth's traditional meaning as the ritualized realization of the pattern of navigation through space on a journey, or pilgrimage to "the center" (Veel, 2003, p. 154) attains a new meaning when studied as an organized mental (and literary) structure. In fact, since it could be said that all "literary thinking is akin to walking a labyrinth" (Bloom \& Hobby, 2009, p. xvi), Poe’s maze is but a more direct expression and actualization of the metaphor within his texts. His reader is made to experience its qualities internally, while a critic-successor might at the same time observe externally the overall, ordered structure of the enterprise. Still, the experience is inevitably marked by a sense of perplexity. As Kristin Veel writes:

Essentially, navigation has to do with the distinction between overview and embeddedness. In the changes in the labyrinth motif one can thus identify alterations in the relation between the view from above and the experience of moving inside the labyrinth. This interweaving of the two different points of view from which the labyrinth can be observed makes it an ambiguous motif, and allows for the labyrinth structure (even in its most simple one-pathed form) to be interpreted as simultaneously order and disorder, clarity and confusion, unity and multiplicity, artistry and chaos. The labyrinth walker, whose vision is constricted and fragmented, is overtaken by confusion, and his/her experience of the labyrinth is one of disorder, multiplicity, and chaos, whereas the labyrinth viewer, able to overlook the complete structure, will get a sense of order, clarity, unity, and artistry. (Veel, 2003, p. 156)

The resulting duality is effectively expressed and embodied within Poe's texts in the figure of the character-narrator, who takes on the qualities of both the "walker" and the "viewer" of the structure, while its effects are transferred to an immersed reader, imprinting them with a play of uncertainties.

Poe's carefully orchestrated dance between the rational and the fantastic is made possible by the unreliable voice of the storyteller, but also makes evident the underlying opposition between the two notions, luring the reader into believing the conflict can be resolved and curiosity satisfied. The existence of this opposition, or perhaps rather the belief in its fundamental character is what Poe's fiction can comfortably rest in. The writer's, reader's and characters' investigations are both enabled and fuelled by a set of assumptions emanating from the context of romantic tradition and that of $19^{\text {th }}$ century America. The "ratiocination" cycle, originating with "The Murders in the Rue Morgue" (2011, p. 63), illustrates this too, by applying an apparently rational method, only to arrive at a truly unbelievable explanation. The readers of the story are inevitably surprised and amazed by the revelation of a razor-wielding man-mimicking Ourang-Outang, and find themselves back in the labyrinth. Poe's explorations rely therefore on the conviction that the parameters of subjective and objective experience are relatively stable, puzzles and cyphers can be solved, the walls of the labyrinth do not shift, and fiction is necessarily stranger than reality.

Frequently described as Poe's literary descendants, both Howard Phillips Lovecraft and Stefan Grabiński openly stated the importance of his literary output for their own work (Grabiński, 1931; Lovecraft, 1974). Their own original textual realities, whether surrounded by hostile and ancient cosmos as in the case of the former writer, or carefully delineated by means of thematic compartmentalization and condensation practiced by the 
latter, carry the touch of Poe's literary brand, along with the mental trace in the form of "scars" and preoccupations of Poe's entrapped reader. In a sense, both authors are explorers, traversing Poe's maze, testing its limits, and adding new remodelled sections to the edifice, while at the same time, despite their overt desire to replicate their antecedent's originality (a paradoxical enterprise, indeed) in terms of style and themes, they too fall into the trap of the labyrinth. Having eagerly absorbed Poe's language, their own investigations are always already filtered through their antecedent's creative and linguistic experience; they are forever haunted by Poe's spectre. Consequently, the Derridean trace, as discussed in Of Grammatology, can here be seen in the form of dynamic (or unfolding) absence of Poe's present(ed) pre-text, a scar forming on the tissue of text.

There is in their texts an implicit need to conquer and capture reality (at times, it seems, stronger than that of Poe), to bind it within the walls of stable categorizations, through application of scientific investigation, a superscience of the spiritual or psychological, a superlogic of obsession, perhaps, which, while dangerous in their revelations, forces, and drives, is expected to offer an explanation.

\section{New, Alien Mechanics}

H. P. Lovecraft's stories frequently revolve around the invasion of the accepted, or normative reality, by ancient (and so historicized), buried or forgotten (and so repressed) and cosmic or extradimensional (and so externalized) forces. While Poe's discourse is secure in its perception and expression of mystified (abnormal) mentality, and satisfied by the quirks of unfathomable human soul, Lovecraft seeks methodical, almost mechanical, elucidation of the masked signified (Joshi, 1996; Joshi \& Schultz, 2001).

In "Arthur Jermyn" the reader accompanies the main character on an investigation into his family's genealogical past, which reveals a pattern of cultural transgressions, miscegenation, and finally interspecies breeding. The reader is presented with a collection of figures, taken as if on a guided tour through the Jermyns' ancestral gallery. The family narrative is historicized via the use of chronological references and localized settings, while the introductory paragraph, itself one of Lovecraft's most famous statements about science, is clearly aimed, if not completely effective, at validating its almost "academic" status:

Life is a hideous thing, and from the background behind what we know of it peer daemoniacal hints of truth which make it sometimes a thousandfold more hideous. Science, already oppressive with its shocking revelations, will perhaps be the ultimate exterminator of our human species - if separate species we be - for its reserve of unguessed horrors could never be borne by mortal brains if loosed upon the world. If we knew what we are, we should do as Sir Arthur Jermyn did; and Arthur Jermyn soaked himself in oil and set fire to his clothing one night.

No one placed the charred fragments in an urn or set a memorial to him who had been; for certain papers and a certain boxed object were found which made men wish to forget. Some who knew him do not admit that he ever existed. (Lovecraft, 1999, p. 14) 
Arthur Jermyn's self-immolation is an attempt at purification, a purging of the world, an erasure of an abomination he discovered himself to be. The ending is thus not unlike in some of Poe's stories. The origin of his destruction is rooted in history, and the act is facilitated by a scientific investigation, with each stage fuelling the character's growing obsession and the reader's horror at the immensity of transgression. However, unlike Poe, Lovecraft relies on otherness, biological, cultural and ethical, to evoke the reaction of the reader. The story portrays life as "hideous" but also as an experience burdened by (ideological) obfuscation, with "daemoniacal" truths being separated from humanity by the distance of insufficient knowledge.

"The Statement of Randolph Carter" is another of Lovecraft's tales, depicting an obsessed investigator exploring the far reaches of consensus reality. The narrator is an apparently reluctant participant in his friend Warren's occult research and accompanies him on the journey to a swamp graveyard, in order to find and enter a portal into another world, inhabited by "demonic" entities. The research is sparked off by a mysterious book of forbidden knowledge, which Carter's partner guards closely, unwilling to share its secrets. Carter is unable to recall any details of their study, a fact which he sees as "merciful" in the end, nor can he admit any conscious interest in his friend's pursuits, instead referring to his state of mind as "reluctant fascination." The latter of course places the decision to interact with the "other world" in a sense beyond his control. As Warren enters the tomb he begins to communicate his experience with the use of a telephone wire. Despite the trappings of scientific research reinforced by the application of the latest technological devices, the words which reach Carter's ears exemplify, once again, Lovecraft's linguistic preoccupation with the "unnamable" and "indescribable," the facets of indeterminate and indeterminable "outer" reality:

God! If you could see what I am seeing!”

I could not answer. Speechless, I could only wait. Then came the frenzied tones again: "Carter, it's terrible - monstrous — unbelievable!"

This time my voice did not fail me, and I poured into the transmitter a flood of excited questions. Terrified, I continued to repeat, "Warren, what is it? What is it?"

Once more came the voice of my friend, still hoarse with fear, and now apparently tinged with despair: "I can't tell you, Carter! It's too utterly beyond thought—I dare not tell you —no man could know it and live - Great God! I never dreamed of THIS!

(Lovecraft, 1999, p. 11; emphasis in original)

Warren orders Carter to immediately flee the place and then falls silent. After a while, and after Carter's numerous desperate attempts to communicate through the wire, a reply finally comes: "YOU FOOL, WARREN IS DEAD!" (Lovecraft, 1999, p. 13; emphasis in original).

Warren is thus literally consumed by the "other side," while the reader, like Carter, is shown to have been foolish to believe the mystery can be pierced. The voice which speaks the final words of the story is described as "hollow, gelatinous, remote, unearthly, inhuman, disembodied" (Lovecraft, 1999, p. 13), the adjectives whose extensive use has gained Lovecraft 
the opinion of poor stylist, while at the same time inspiring a special brand of occasionally "reluctant" fascination in his followers. Simultaneously "gelatinous" and "disembodied," the origin of the voice brings metonymic associations of at once organic and spiritual nature.

Lovecraft clearly and intentionally externalizes the threat of identity's dissolution and does it to find his own way out of the labyrinth of Poe's legacy. Intent on developing and building upon his master's voice, he is, however, unable to escape either the cultural fears or personal insecurities, creative, ethical and otherwise. Jermyn's self-destruction and Warren's extinction resemble Poe's silencing of the narrative voices, but are marked by a reactionary response towards the modernist crisis of reference. The reality they inhabit has been transformed, the rules shifted to accommodate an "alien evil" greater than human inadequacy and weakness. Lovecraft draws his horror out of his readers' and his own anxiety about the precarious state of ideas and values, which, when translated into fiction, emerges in the form of artificial mythology, alien physiology, and non-Euclidean geometry, all designed to explain the world where things fall apart.

\section{Obsession's Will to Empower}

Stefan Grabiński was an author of novels, plays, and short stories which can be broadly classified as weird fiction. Frequently referred to as "Polish Poe," or "Polish Lovecraft," Grabiński wrote tales in the genre he himself called "psychofantasy" or "metafantasy" (Grabiński, 2012, p. 302). Both terms immediately evoke associations with inner, rather than outer experience of characters and textual world as foregrounded in his writing, and suggest a special significance awarded to products of psyche, be they fantasies, nightmares, hallucinations, desires, or phantom objects.

Grabiński's confessed admiration of Poe's work and fascination with his literary ideas is clearly visible in his selection of themes, his chosen vehicle of expression and stylistic precision. Like Lovecraft, he embraces signs of scientific and technological progress and employs them in his writing, constructing a powerful and realistic vision of a dynamic world, inhabited by characters whose actions (and ideas) affect and transform it. Contrary to Lovecraft's projections of cosmic magnitude, however, Grabiński sharply narrows his focus to the point at which a story becomes an intimate encounter with the protagonist and their perception of reality evoked in the text.

"Vengeance of the Elementals" tells the story of fire chief Antoni Czarnocki who, apart from being an active firefighter and a veteran of numerous infernos, is a theorist of flames, conducting extensive research into the phenomenon of fires:

The fruits of this long-standing research were the special "fire maps" and "fire modifications" drawn up by him. On the first were emphasized places, buildings and houses which had passed through some catastrophe, no matter if the traces of the fire were eliminated and the damage repaired, or if the fire site had been left to its own fate. The plans called "fire modifications" underlined the changes that had occurred in the arrangement of homes and buildings as a result of a fire disaster; any shift or the slightest alteration was marked with amazing pedantry. (Grabiński, 1993, p. 73) 
Czarnocki's work is an attempt at mastering the contingency of fire-related incidents by means of science, but perhaps more importantly, it strives to connect the statistical data to the dynamic morphology of urban space, which as a fire chief he sees as his domain and responsibility. His approach, though seemingly based on scientific principles, results in revelations of unusual nature:

Connecting various fire sites with lines, he became convinced that in four out of five times the fire points created outlines of strange figures. Primarily these were the shapes of short, funny beings that sometimes reminded one of child freaks, at other times, of animals - little monkeys with long, playfully turned tails, agile bow-legged squirrels, extremely hideous talapoins. (Grabiński, 1993, p. 73)

This discovery he also translates into a physical form, this time of an artistic kind - the Album of the Fire Elementals:

The second part of this work was Fragments and Designs - a multitude of grotesque figures, incomplete forms, barely developed ideas. Inside were sketches of vague heads, fragments of trunks, parts of arms and legs, segments of hairy, spread-out paws, interspersed with halftwisted figures, mangled things and tentacle growths. (Grabiński, 1993, p. 73)

Filtered through Czarnocki's perception, the fruit of his scientific labour attains the form of miniature monstrosities, which, after immersing himself in the study of mythology, folklore and mystical writings, he becomes convinced are entities responsible for the appearance of fires.

Perhaps as a result of his obsession, Czarnocki also acquires an almost uncanny ability to avoid any harm caused by flames, gaining him a nickname of "fireproof." Confident in this invulnerability, Czarnocki wages war on the elementals, which apparently respond in kind, trying to destroy him indirectly, by means of a falling beam or a heavy crossbar intended to crush him, or clouds of carbon dioxide in his home. Czarnocki prevails and moreover finds himself an addressee of hidden messages encoded in patterns visible on the surface of unburned coal. Despite being apparently fireproof, the fire chief has a weakness, an affliction in the form of involuntary astral projection, which in the end allows the elementals to possess his body and start multiple fires in key locations of the city. His body confined to a mental institution, Czarnocki's spirit is left behind, with nowhere to return to.

Another story by Grabiński which discusses the consequences of obsessing mind is "The Area." The protagonist, Wrześmian, is an author of strange and enigmatic fiction, misunderstood, or perhaps never really understood at all, who stops writing and removes himself from the public view completely, choosing instead to exist solely in the world of his dreams, fantasies and fictions. Wrześmian is a believer in the creative power of thought, its ability to transcend laws of nature and affect and shape the material world:

He had acquired as time went on the firm conviction that any thought, even the most audacious, that any fiction, even the most insane, can one day materialize and see its fulfilment in space and time.

"No person thinks in vain; no thought, even the strangest, disappears fruitlessly," he used to repeat many times to his circle of friends and acquaintances. (Grabiński, 1993, p. 29) 
The claim seems in a sense to echo Ligeia's rebellious statement about the power of will, its ability to conquer death.

As years go by, Wrześmian's ideas, for lack of expression through projection on paper, gain even more vitality and finally a life of their own. He becomes fascinated with an abandoned and empty house, which he observes for days on end until one evening he sees a grotesque face in the window, then another one, and another and so on. The empty villa becomes populated with his materialized thought content, and so he has no choice but to investigate. As he sneaks into the house, he becomes surrounded by a host of apparitions, demanding to be given "full" expression:

They surrounded him in an increasingly closed circle. From pale, bloodless lips flowed out a menacing whisper: "It's him! It's him!" He stopped and looked defiantly at the throng: "What do you want from me?" "Your blood! We want your blood! Blood! Blood!" "What do you want it for?" "We want to live! We want to live! Why did you call us out from the chaos of non-existence and condemn us to be miserable half-corporeal vagrants? Look at how weak and pale we are!" (Grabiński, 1993, p. 35)

Unable to escape, Wrześmian is consumed by the apparition in a gory feast of blood and flesh.

The final scene of the story shows a vat standing in the corner of the house, for years a receptacle of the writer's discarded thoughts, rejected ideas, and half-conscious fantasies, bubbling with oozing matter. Then something emerges:

A couple of large, distended bubbles escaped, and a misshapen stump of a hand appeared. Some sort of torso or framework emerged from the depth, dripping with water, covered with mould and a cadaverous putridity - maybe a man, beast or plant. This monstrosity glinted its amazed face toward the sky, opened spongy lips wide in a vague imbecilic-enigmatic smile, extracted from the vat legs twisted as a thicket of coral, and, shaking the water off, started to walk with an unsteady, swinging step.... (Grabiński, 1993, p. 35)

The entity, a sort of mental version of Frankenstein's creature, walks out of the house and into the world, and finally vanishes in the distance with the first light of dawn.

Grabiński's experience in the maze-like literary house of Poe is thus far more internal and intimate. His characters are shown to collapse onto their own mental plane, giving the reader a sense of closing, if not closure, and enhancing the claustrophobic nature of inner experience. Even more than Lovecraft, with his emphasis on the randomness, chaos and insignificance of human existence, Grabiński traces in fascinating and painful detail his characters' mental journeys, their odyssey towards the inevitable dissolution.

\section{Persistent Amazement}

Both Lovecraft and Grabiński exhibit the symptoms characteristic for the victims of entrapment in the textual labyrinth. There is in their writing an integral and inseparable strain of Poe's literary diction; they are always and already his readers, prior to their own voice, who speak in a language of horror, haunted, but ultimately made complete and possible 
by their antecedent's never-absent spectre. Its persistence may, in fact, lead us to call into question, and perhaps nullify, even the seemingly clear antecedent-to-successor relation. As Marek Wilczyński states:

in "the extraordinary case" of Lovecraft and Poe, both components of the hypertextual relationship lose their proper identity so that it becomes impossible to tell one from the other ... the borderline separating the hypertext from the hypotext is erased and the fundamental of their sequence annihilated. (1992, p. 168)

A similar argument may be put forward in the (equally "extraordinary") case of Grabiński, whose Poesque "phantom scar" is more structural than thematic, making his "haunting" a constructivist enterprise.

China Miéville, one of the contemporary heirs to the horror tradition, describes Grabiński's work in the following words:

Where Poe's horror is agonised, a kind of extended shriek, Grabinski's is cerebral, investigative. His protagonists are tortured and aghast, but not because they suffer at the caprice of Lovecraftian blind idiot gods: Grabinski's universe is strange and its principles are perhaps not those we expect, but they are principles - rules - and it is in their exploration that the mystery lies. (Miéville, 2003, para. 3)

As the wellspring of essence, which to some extent nourished Poe's romantic playfulness, this insidious paradigmatic oscillation between the rational and the fantastic appears to have dried out in Lovecraft and Grabiński's time, the two authors are forced to blaze a new path out of both Poe's and their own maze of textual, cultural and psychological obsessions. To quote Harold Bloom once again, "All literary influence is labyrinthine; belated authors wander the maze as if an exit could be found, until the strong among them realize that the windings of the labyrinth all are internal" (Bloom \& Hobby, 2009, p. xvi). Poe's maze, its spectral half-presence, thus serves as a "missing link" between the two masters of weird fiction (Wilczyński, 2008, p. 536), a transatlantic bridge and an "interpretant connecting Lovecraft and Grabiński” (Wilczyński, 2008, p. 531). Having adopted different trajectories and artistic philosophies in reaction to the challenges of modernity (Lovecraft's reactionary, and at times, nihilistic mode and Grabiński's earnest, if concerned, fascination with progress and technology's impact on individual psyche), the two artists clearly share the common origin of their preoccupations. As the American reaches out to the dark stars, antediluvian past and other dimensions, the Polish gothicist looks inside and finds terror "not of Germany, but of the soul" (Poe, 1984, p. 129). Consequently, Lovecraftian protagonists seek the understanding of the hidden mechanics of the world they inhabit, be they genetically, cosmologically, or historically regulated, while Grabiński's characters examine the limits and principles of psychological, emotional and creative power. The obsessions they suffer from are at once life-threatening and life-defining, fuelling investigations which are always already failed, but whose failures mediate and sustain the spectral half-life and the "extended shriek" of Poe's labyrinthine prose. 


\section{References}

Bloom, H., \& Hobby, B. (Eds.). (2009). The labyrinth. New York: NY: Blooms Literary Criticism.

Derrida, J. (1997). Of grammatology. Baltimore, MD: Johns Hopkins University Press.

Grabiński, S. (1931). Książę fantastów (E. A. Poe). Studium literackie. Lwowskie Wiadomości Muzyczne i Literackie, 3, 1; 4, 1-2; 5, 2-3.

Grabiński, S. (1993). The dark domain. Sawtry, UK: Dedalus.

Grabiński, S. (2012). Wichrowate linie (Utwory rozproszone). Kraków, Poland: Agharta.

Joshi, S. T. (1996). A subtler magick: The writings and philosophy of H.P. Lovecraft. Berkeley Heights, NJ: Wildside.

Joshi, S. T. \& Schultz, D. E. (Eds.). (2001). An H. P. Lovecraft Encyclopedia. Westport, CT: Greenwood.

Lovecraft, H. P. (1973). Supernatural horror in literature. New York, NY: Dover Publications.

Lovecraft, H. P. (1999). The Call of Cthulhu and other weird stories. New York, NY: Penguin.

Miéville, C. (2003, February 8). Trainspotting: China Miéville bemoans the dearth of translations of Stefan Grabinski's pioneering horror fiction. The Guardian. Retrieved from https://www.theguardian.com/books/2003/feb/08/featuresreviews.guardianreview20

Poe, E. A. (1984). Edgar Allan Poe. Essays and reviews. New York, NY: Library of America.

Poe, E. A. (2011). Edgar Allan Poe: Collected works: Stories and poems. San Diego, CA: Canterbury Classics.

Veel, K. (2003). The irreducibility of space: Labyrinths, cities, cyberspace. Diacritics, 33(3-4), $151-172$.

Wilczyński, M. (1992). Supplementing the abyss-H. P. Lovecraft and E. A. Poe. Studia Anglica Posnaniensia, 24, 159-168.

Wilczyński, M. (2008). Secret passage through Poe: The transatlantic affinities of H. P. Lovecraft and Stefan Grabinski. Studia Anglica Posnaniensia: International Review of English Studies, 44: $531-538$. 